\title{
Inventory Studies on Various Livelihood Activities along with Agroforestry Techniques in the Adjoining Land of Fringe areas for Restoration of the Sunderbans under Humid Climate in India
}

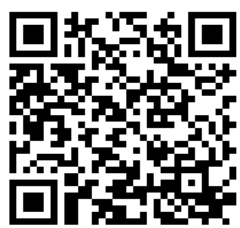

\section{Subhabrata Panda ${ }^{1 *}$, Pratap Kumar Dhara ${ }^{2}$, Smritikana Sarkar ${ }^{1}$, Nitai Charan Das ${ }^{2}$ and Gokul Benode Roy ${ }^{2}$} ${ }^{1}$ AICRP on Agro forestry, India

${ }^{2}$ Department of Soil and Water Conservation, India

Submission: November 24, 2016; Published: January 16, 2017

*Corresponding author: Subhabrata Panda, AICRP on Agroforestry, Jhargram, BCKV, Paschim Medinipur- 721 507, West Bengal, India,

Email: subhabratapanda@gmail.com

\begin{abstract}
On the southern most part of the Genetic delta there pervades the Sunder bans Biosphere Reserve, one of the largest mangrove forests in the world. Inventory studies in the fringe areas have been done for creating congenial situation in minimizing human interference in the biosphere. Innovation of agro forestry practice would prove the best alternative support for people inhabiting that area for their most dependence on their own agro forestry products for avoiding the biosphere forest products for their livelihoods.
\end{abstract}

Keywords: Sunder bans; Fringe areas; Agroforestry

\section{Introduction}

On the southernmost part of the Genetic delta both in India and Bangladesh there pervades the Sunder bans, the land of one of the largest mangrove forests in the world. Those two countries share about one third and two third of that unique landscape accordingly. The Sunder bans extend about $265 \mathrm{~km}$ from river Hooghly in the west to the Meghna in the east; and about $125 \mathrm{~km}$ from the Bay of Bengal in the south to the permanently settled land in the northern fringe in the districts of Bakherganj, Jessore, Khulna of Bangladesh and the districts of North and South 24 Parganas of West Bengal in India. The Suder bans is spread over on about 102 islands in India. In the context of restoration of biosphere reserves in the Sunder bans, management of human livelihoods in the fringe areas is the sole concern. Fringe area is part of estuarine geomorphic feature up to the edge of biosphere reserve. Consequently it is to be noted that livelihoods of people in the fringe areas are dependent on various bio components of forest-estuarine eco zone. That ecologically sensitive zone is also a potential area for innovating agro forestry practice in adjoining land of fringe areas for enhancing livelihood capacity of through extra income generation which would be a stable source of property generation and to meet the emergency causes in domestic life.

\section{Materials and Methods}

Inventory studies were done on various bio components in the fringe areas in the Indian part of the Sunderbans, comprising domestic habitats, agricultural lands, estuaries and fallow lands. Those included A. mangrove, the major component of the Sunder bans Biosphere Reserve.,

B. mangrove based forest products like honey, bee wax, etc.,

C. fishery, prawn culture and crab culture,

D. duckery,

E. poultry, 
F. agriculture and agro-based activities like (a) palm and jaggery (gur) making industry, (b) scented grass and eucalyptus oil extraction, (c) commercial production of horticultural crops like watermelon and chilli, etc. (d) coir industry, (e) allied small scale processing industry, vii) dry fish production and viii) fish and poultry feeds manufacturing industry. Possibilities of introducing agro forestry practice in the adjoining lands of fringe areas has been analysed for ensuring extra income in that ecologically sensitive area aimed at less interference in the biosphere reserve [1].

\section{Discussion}

Sustainable use is defined by the Convention on Biological Diversity (CBD) as: "The use of components of biological diversity in a way and at a rate that does not lead to the long-term decline of biological diversity, thereby maintaining its potential to meet the needs and aspirations of present and future generations [2].' To restore such unique sustainability in use of biological resources of the Sunderbans, inventory surveys for different biocomponents in the fringe areas would be of very much help as follows [1].

a. Root net works of mangrove is the natural shelter of Tiger prawn for their breeding. So, collection prawn seeds through netting should be away from newly born mangroves.

b. Catch of Hilsa to be so timed at the return of fish stocks to the sea.

c. In case of inland fish such criteria may fixed accordingly as per the economic

Endowment position of the beneficiaries.

d. Demand of fuel wood supply can be meet up from creating provision for solar chullah

And other alternative sources of energy. In this regard practice of agro forestry would

Be a guaranteed alternative.

e. Innovating integrated agricultural systems in association with horticulture, agro forestry

Including integrated aquaculture would be the best alternative.

f. Some agro-based small scale cottage industries like extraction of scented oil,

Eucalyptus oil, making of jaggery from date palm, Asian palm, coir making, dry fish

Production, etc. can secure extra income.

g. Practice of agro forestry and agro forestry based various products and small scale cottage industries and generation of wood lots outside the biosphere reserve would prove a stable alternative for satisfying various domestic enlightenments including fulfilling emergency demands and creating additional properties towards domestic lives of the peoples living in the fringe areas without any burdens on the forest of biosphere reserve.

Agro forestry systems are to be practiced on the lands adjoining the fringe areas outside the biosphere reserve with a regard not to interfere the biosphere reserve ecosystem in no ways. From the inventory surveys it was revealed that some trees could be introduced as tree or silvi components in the proposed agro forestry systems [3]. The prospective tree species (for agro forestry) for Sunder bans areas are given in Table 1.

Table 1: Prospective tree species (for agro forestry) for adjoining fringe areas in the Sunderbans.

\begin{tabular}{|c|c|}
\hline Particulars & $\begin{array}{c}\text { Agro Forestry Management } \\
\text { Information }\end{array}$ \\
\hline Tree Component : Name & $\begin{array}{c}\text { Acacia auriculaeformis, } \\
\text { Eucalyptus sps., Dysoxylum } \\
\text { binectarifaeum, Leucaena } \\
\text { leucocephala, Mangifera indica, } \\
\text { Ziziphus mauritiana, Acacia } \\
\text { nilotica, Tectona grandis, } \\
\text { Coconut, Anthocephalus } \\
\text { Cadamba. }\end{array}$ \\
\hline Boundary / Block / in field & Boundary and Block plantation \\
\hline Spacing & $\begin{array}{c}5 \mathrm{~m} \times 5 \mathrm{~m}, 6 \mathrm{~m} \times 6 \mathrm{~m}, 8 \mathrm{~m} \times 6 \mathrm{~m} \text { and } \\
8 \mathrm{mX} 8 \mathrm{~m}\end{array}$ \\
\hline Pit size & $60 \mathrm{~cm} \times 60 \mathrm{~cm}$ X $60 \mathrm{~cm}$ \\
\hline $\begin{array}{l}\text { Any other management } \\
\text { requirement Intercrop : Name }\end{array}$ & $\begin{array}{c}\text { Rice, Jute, Mustard, Sugarcane, } \\
\text { Vegetables. }\end{array}$ \\
\hline
\end{tabular}

Various agro forestry systems to be practiced on the lands adjoining fringe areas in the Sunder bans are enlisted in Table 2.

Table 2: Agro forestry systems to be practised on the lands adjoining fringe areas in the Sunderbans.

\begin{tabular}{|c|c|}
\hline $\begin{array}{c}\text { Recommended Agroforestry } \\
\text { Technology }\end{array}$ & $\begin{array}{c}\text { Fruit-based agroforestry, Agri- } \\
\text { silviculture,Horti-apiculture,and } \\
\text { Aqua-forestry }\end{array}$ \\
\hline $\begin{array}{c}\text { Recommended for normal/ } \\
\text { degraded land (type of } \\
\text { degradation) }\end{array}$ & $\begin{array}{c}\text { Fruit- based Agroforestry, Agri- } \\
\text { silviculture }\end{array}$ \\
\hline $\begin{array}{c}\text { Recommended for small/ } \\
\text { marginal/ large farmers }\end{array}$ & $\begin{array}{c}\text { Marginal \& Large farmers: } \\
\text { Fruit- based Agroforestry, Agri- } \\
\text { silviculture, Horti-apiculture and } \\
\text { Aqua-forestry.Small : Fruit- based } \\
\text { Agroforestry }\end{array}$ \\
\hline
\end{tabular}

\section{Conclusion}

A. Restoration of biosphere reserve of the Sunder bans needs innovation of integrated Agriculture systems including horticulture, aquaculture, and practice of agrobased small Scale cottage industries for making people of fringe areas self sufficient with their Products through viable market linkage.

B. Innovation of agro forestry practice including aquaforestry would prove a timely Accepted best agro-technique 
with other associated efforts based on agro forestry products For restoration of the Sunder bans Biosphere Reserve.

\section{References}

1. Mandal AK (2003) The Sundarbans of India: A Development Analysis. ISBN 8173871434, 9788173871436. Indus Publishing Company, The University of Michigan, USA.
2. UNESCO / ICCROM / ICOMOS / IUCN (2012) World Heritage Resource Manual: Managing Natural World Heritage. ISBN 978-92-3-001075-1, UNESCO World Heritage Centre, 7, Place de Fontenoy75352 Paris 07 SP, France, Europe, p. 57.

3. Dhara PK (2016) Humid and Sub-Humid Region - BCKV, Jhargram (West Bengal). In: Chaturvedi OP, et al. (Eds.), Agroforestry Technologies for Different Agro-Climatic Zones of the Country, ICAR-Central Agroforestry Research Institute, India, p. 51-64.

\section{Your next submission with Juniper Publishers} will reach you the below assets

- Quality Editorial service

- Swift Peer Review

- Reprints availability

- E-prints Service

- Manuscript Podcast for convenient understanding

- Global attainment for your research

- Manuscript accessibility in different formats (Pdf, E-pub, Full Text, audio)

- Unceasing customer service

Track the below URL for one-step submission https://juniperpublishers.com/online-submission.php 